\title{
OPTIMALISASI TRANSPORT SELEKTIF ION Ni(II) TERHADAP Cd(II) DENGAN ZAT PEMBAWA OKSIN MELALUI TEKNIK MEMBRAN CAIR FASA RUAH SECARA SIMULTAN
}

\author{
Vera Tri Ningsih ${ }^{1,2}$, Admin Alif ${ }^{2,3}$ dan Hermansyah Aziz ${ }^{2,3}$ \\ ${ }^{1}$ SMAN 1 Kec. Lareh Sago Halaban Kab. Limapuluh Kota \\ ${ }^{2}$ Program Studi Kimia Pasca Sarjana Universitas Andalas \\ ${ }^{3}$ Jurusan Kimia , FMIPA, Universitas Andalas Padang
}

\begin{abstract}
The selective transport of $\mathrm{Ni}(\mathrm{II})$ to $\mathrm{Cd}(\mathrm{II})$ through simultaneously liquid membrane technique has been investigated. The cell membrane was made by mixturing $\mathrm{Ni}$ (II) and $\mathrm{Cd}$ (II) ions at concentration as $3.41 \times 10^{-4} \mathrm{M}$ and $1.78 \times 10^{-4} \mathrm{M}$ respectively as source phase, oxine in chloroform as membrane phase and $\mathrm{Na}_{2}$ EDTA solution as receiving phase. Concentration of recidual $\mathrm{Ni}$ (II) and $\mathrm{Cd}(\mathrm{II})$ ions in source phase transported to receiving phase was measured by Atomic Absortion Spectrofotometry (AAS). The results showed the at optimum condition of $\mathrm{Ni}(\mathrm{II})$ and $\mathrm{Cd}(\mathrm{II})$ transport occurred at source phase of $\mathrm{pH} 7$, oxine concentration $0.001 \mathrm{M}$ in chloroform and $0.04 \mathrm{M}$ $\mathrm{Na}_{2}$ EDTA solution $\mathrm{pH}$ 7. In this condition, $\mathrm{Ni}(\mathrm{II})$ and $\mathrm{Cd}(\mathrm{II})$ transport selectivity was found $80.89 \%$. From the experiment, it was found that the transport rate constant from source phase to membrane phase $\left(\mathrm{k}_{1}\right)$ for $\mathrm{Ni}(\mathrm{II})$ ( 0.7544 per hour) smaller than $\mathrm{Cd}(\mathrm{II})$ (1.3800 per hour ), on the other hand the transport rate constant from membrane phase to receiving phase ( $\left.\mathrm{k}_{2}\right) \mathrm{Ni}$ (II) $(2.7580$ per hour) greater than $\mathrm{Cd}$ (II) (1.3790 per hour). The phase-to-phase transport of $\mathrm{Ni}(\mathrm{II})$ and $\mathrm{Cd}(\mathrm{II})$ was consecutive first order reaction.
\end{abstract}

Keywords : bulk liquid membrane, oxine, technique

\section{DAFTAR PUSTAKA}

1. C.A. Molina, L. Victoria and J. A. Ibanez, Characterization Membrane System. Complex Character of Permeability from Electric Model. J. Phys. Chem., 101: 10323-10331, (1997).

2. M. Mulder, Basic Principle of Membrane Technology, Kluwer Academic Publisher, Do Rsrecht, 1991, 244-249.

3. A. Safavi, E. Shams, Selective and Efficient transport of $\mathrm{Hg}(\mathrm{II})$ through Bulk Liquid Membrane Using Methyl Red as Carrier, J. Membr. Sci., 144: 37-43, (1998).

4. Ulewicz, Mobgorzata, W. Walkowiak, Separation of Zinc and Kadmium Ions from Sulfate Solution by Ion Flotation and Transport Through Liquid Membranes, Physicochemical Problems of Mineral Processing, 2003, 37: 77-86.

5. C. Aydiner, M. Kobya, E. Demirdas, Cyanide Ions Transport from Aqueous Solution by Using Quaternary Ammonim Salts Through Bulk Liquid Membrane, Desalination, 180: 139-150, (2005).

6. A. O. Saf, S. Alpaydin, A. Sirit, Transport Kinetics of Chromium (VI) Ions Through a Bulk Liquid Membrane Containing p-tert-Butil Calix[4] arene 3-Morpholino Propyl Diamide Derivative, J. Membr. Sci., 283: 445-448, (2006).

7. G. R. Leon, D. los Santos, and M. A. Guzman, Reduction of Sodium and Chloride ion Content in Aqueous Solutions by Bulk Liquid Membranes: a Kinetic Approach, Desalination, 168: 271275, (2004). 
8. I. A. Vogel, Buku Ajar Vogel: Kimia Analisis Kuantitatif Anorganik, terjemahan A. Hadyana dan Harmita, 4, Penerbit Buku Kedokteran, 1994, 304-312.

9. A. Alif, O. N. Tetra, H. Aziz, dan Emriadi, Pengaruh ion Cd(II) dan Fe(II) Terhadap Transpor $\mathrm{Cu}(\mathrm{II})$ Melalui Teknik Membran Cair Fasa Ruah, J. Kimia Andalas, 11(1): 6-9, (2005).

10. A. Alif, A. Amran, H. Aziz, dan E. Pelita, Permiasi Ni(II) Melalui Membran Cair Fasa Ruah dengan Oksin sebagai Pembawa, J. Kimia Andalas, 7(2): 61-79, (2001).

11. L. Longquan, W. Cheng, dan L.Yadong, Separation of Cobalt and Nickel by Emulsion Liquid Membrane with the Use of EDTA as Masking Reagent. J. Membr. Sci., 135: 173-177, (1997).

12. J.A. Dean, Lange's Handbook of Chemistry, $3^{\text {th }}$.Ed. Mc Graw Hill, 1985.

13. S. Altin, N. Demircioglu, I. Peker, dan A. Altin, Effects of Acceptor Phase and Donor Phase Properties on Sodium Ions Transport from Aqueous Solutions Using Liquid Membrane Systems, J. Colloids and Surfaces, 14369: 1-8, (2007). 